\title{
The perfective auxiliary $o$ in the Moldavian variety. Diachrony and synchrony
}

\author{
Mădălina Botez ${ }^{1 *}$, Adina Dragomirescu ${ }^{1,2,3 *}$ \\ ${ }^{1}$ Faculty of Letters, University of Bucharest, 5-7 Edgar Quinet St., 010017 Bucharest, Romania \\ 2 "Iorgu Iordan - Al. Rosetti" Institute of Linguistics, 13 Calea 13 Septembrie, 050711 Bucharest, Romania \\ ${ }^{3}$ The Research Institute of the University of Bucharest, 36-46 Mihail Kogălniceanu Bd., 050107 Bucharest, Romania
}

\section{Article info}

History:

Received May 3, 2017

Accepted May 13, 2017

Published September 30, 2017

Key words:

Moldavian variety

auxiliary

compound past

assimilation

cliticization

\begin{abstract}
The aim of the paper is the analysis of the perfective auxiliary $o$ in the Moldavian variety. The paper starts by discussing the origin, the dating, the localization, and the evolution of the form $o$ in Romanian, until the $19^{\text {th }}$ century. Against the literature and the linguistic atlases according to which the form $o$ is general in Moldavia, our corpus study has revealed that the forms $a$ and $a u$ are also used alongside the form $o$, under the influence of the standard language; moreover, the form $o$ shows a tendency towards specialization for contexts with multiple cliticization.

Our analysis-which contributes to the understanding of the phonologymorphology interface-can be extended to the study of other regional varieties of Romanian.
\end{abstract}

\section{Introduction}

In this paper, we analyse the perfective auxiliary $o\left(3^{\text {rd }}\right.$ person, singular and plural) in the Moldavian variety of Romanian. The starting point of our research is the remark that the information in the dialectological treatises and the linguistic atlases differs to a certain extent from what we have found in the examination of the dialectal texts. The treatises mention that the form $o$ is used in Moldavia for the $3^{\text {rd }}$ person singular and plural, a fact confirmed by the linguistic maps, whereas the situation found in texts is different: alongside the form $o$, in this region the standard forms $a$ and $a$ are also used syncretically, both for the singular and the plural. In what follows, we will try to identify the factors that influence the usage of the forms $o$, on the one hand, and $a / a u$, on the other hand. This research can be extended to other regional varieties of Romanian, in which more than one form of the perfective auxiliary is used.

First of all, we briefly review the data discussed in the literature related to the form o in the DacoRomanian varieties and the hypotheses formulated with respect to the origin of the form $o(\$ 2)$. We then tackle the history of the form $o$, starting with its first attestations and ending with data from the $19^{\text {th }}$ century (\$3). Finally, we analyse the distribution of the form $o$ and the parallel forms a/au in certain maps from the linguistic atlases and in dialectal texts from Moldavia ( $\$ 4$ ). In $\$ 5$, we draw the conclusions and formulate an account for the parallel usage of the two forms of the auxiliary.

\section{The auxiliary $o$ in dialectal Daco-Romanian}

In this section, we present the distribution of the form $o$ in the present-day varieties, as described in the dialectological studies, and the hypotheses on the origin of this form.

\footnotetext{
*Email addresses: madalynabotez@yahoo.com(MB),adina_drag@yahoo.com(AD).
} 


\subsection{The distribution of the form $\boldsymbol{o}$ in the present-day varieties}

According to the dialectological studies, one of the features that distinguish the Southern varieties from the Northern ones is the form of the perfect auxiliary for the $3^{\text {rd }}$ person: $a$ in Wallachia and $o$ in the Northern varieties, both for singular and plural.

In the table below, we have synthesised the information from Caragiu Marioțeanu et al. (1977, p. 142, $149,158,162,167)$ and TDR $(1984$, p. 179, 225, 263, 309, 337), in order to draw a general image of the geographical distribution of the $3^{\text {rd }}$ person form of the perfective auxiliary in Romanian.

\begin{tabular}{lcc} 
Variety & $3^{\text {rd }}$ person singular & $3^{\text {rd }}$ person plural \\
\hline Wallachia & $a$ & $a$, au \\
Moldavia & o & o, au \\
Banat & o & or \\
Crișana & $\boldsymbol{o}$ & $\boldsymbol{o}$, or, au \\
Maramureș & $\boldsymbol{o}$ & $\boldsymbol{o}$, or \\
Transylvania & $\boldsymbol{o}$ & $\boldsymbol{o}$, or
\end{tabular}

Table 1: The distribution of the auxiliary $o$ in Daco-Romanian varieties

The table above shows that, according to the dialectological treatises, the form $o$ is used both for the singular and the plural in all the Northern varieties, except for the Banat, where it is used only for the singular. Of the Northern varieties, the Moldavian one is characterised by the absence of the plural form $o r$, therefore the form $o$ is the syncretic expression of the singular and the plural.

\subsection{Hypotheses on the origin of the form $\mathrm{o}$}

As we will extensively show in $\$ 3$, the form $o$ is not attested in the first period of old Romanian. Thus, the form $o$ emerged at a later stage and its origin is controversial. Frâncu (1969, p. 303) offers a summary of the emergence of the form $o$ :

(i) the form $o$ replaced the form $a$ in specific conditions (Coteanu, 1961, p. 89): first, the $3^{\text {rd }}$ person plural or occurred (it extended from the future auxiliary a vrea 'want', through the future-in-the-past with a presumptive value, which is also a past tense), and then the singular form $o$ was recreated; for the variety considered in this paper, this hypothesis is hard to support, because or is not used at all in Moldavia for the plural;

(ii) $o<a u$ (< Lat. HABUNT) by assimilation, a hypothesis put forth by Frâncu (1969, p. 303), using old Romanian data (see $\$ 3$ );

(iii) o has a mixed origin: a avea 'have' and a vrea 'want'.

As noticed by Coteanu (1961, p. 89) and Frâncu (1969, p. 303), the form $o$ cannot derive from $a$, because such a phonetic change is impossible in Romanian. Frâncu (1969, p. 305-306) argues against hypotheses (i) and (iii), showing that: the areas of perfective $o$ and future $o$ do not overlap, the $o$-future is more recent than the compound past with $o$, and the form or (attested only in Banat, according to Frâncu) dates from the beginning of the $19^{\text {th }}$ century; therefore, the form $o$ of the compound past probably occurred before the contamination between a vrea 'want' and a avea 'have', recently attested in Banat.

After analysing, in the next section, the data from old Romanian, we will adopt the hypothesis that $o$ originates in au.

\section{The auxiliary $o$ in diachrony}

The $3^{\text {rd }}$ person perfective auxiliary $o$ was not of much interest for researchers. The authors which have taken up this issue, Frâncu (1969), Gheție (1975), and Zamfir (2007) arrived at (slightly) different results, because the corpus on which their analyses are based is different. 
3.1. Frâncu (1969, p. 304) shows that the form $o$ is old enough, being attested in documents from the Northern area, ever since the beginning of the $17^{\text {th }}$ century. According to his research, the form $o$ is absent not only from religious texts (a fact which shows that it did not belong to the standard/literary language), but also from the Wallachian documents. It has only one attestation in the oldest version of Alexandria, the 1620 variant (1). Frâncu (1969, p. 304) also notices that the form $o$ is not attested in the Moldavian chronicles, because the copies preserved were made by Wallachian scribes.

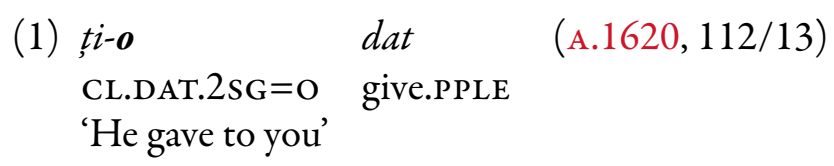

Arguing for his hypothesis on the origin of the form o (see supra, \$2.2), Frâncu (1969, p. 300-304) also analyses the distribution of the forms $a$ and $a u$ in old Romanian. The author notices that, in the $16^{\text {th }}$ century, the form $a$ is not attested in texts with rhotacism and in Coresi's printings (in which the form au is exclusively used, both for the singular and the plural), the first religious text containing the form $o$ being Po.1582. Frâncu (1969, p. 301) shows that the usage of $a$ is not just a writing error; rather, it illustrates the involuntary and unconscious penetration of oral elements in the written language. Thus, the form $a$ does not belong to the literary language of the $16^{\text {th }}$ century, but it was probably used in the spoken language. In the $17^{\text {th }}$ century, $a$ was frequently used in Wallachia (Frâncu, 1969, p. 302). Therefore, in the $17^{\text {th }}$ century, there were two areas for the $3^{\text {rd }}$ person singular of the perfective auxiliary: a Southern area, where $a$ and $a u$ were used, and a Northern area, where $o$ and $a u$ were used.

Frâncu (1969, p. 304) shows that the initial stage of the assimilation of $a$ from au by the rounded vowel $u$ is attested in inscriptions from Maramures, dating back to the first half of the $17^{\text {th }}$ century:

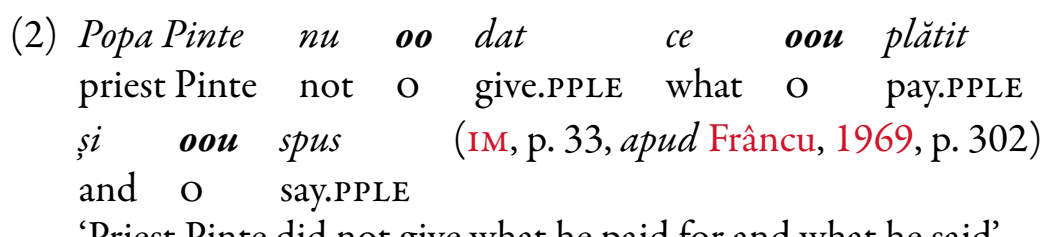

Frâncu (1969, p. 304) notices that the change $a u>o$ by assimilation occurs especially when the auxiliary is preceded by a rounded vowel, namely the direct object $o$ ( $3^{\text {rd }}$ person singular feminine accusative clitic), which was preverbal in old Romanian, and he illustrates this case with examples like the following:
(3) a. Această carte o-u[=oau $]$ cumperat popaLupu (1720, MM, IM, p. 33) this book $\mathrm{O}=\mathrm{AUX}$.PERF.3sg buy.PPLE priest Lupu 'Priest Lupu bought this book'
b. Cum o-u $[=o$ au $] \quad$ crescut $\quad(1619, \mathrm{DR}, 45)$ how $\mathrm{O}=\mathrm{AUX} . \mathrm{PERF} .3 \mathrm{SG} \equiv \mathrm{PL}$ raise.PPLE 'how he/they raised it'
c. Cum au luat pre Despina demică de how AUX.PERF.2sG take.PPLE DOM Despina of little that $\boldsymbol{o}$ [=oau] ținut el și o crescut el ca ofată $\mathrm{O}$ (o=AUX.PERF.3SG) keep.PPLE he and $\mathrm{O}$ raise.PPLE he like a daughter a lui și o brănit 30 de ani (1615, Mold, DB, 111) GEN his and $O$ feed.PPLE 30 of years 'How he took Despina when she was a little girl and he kept her, he raised her and fed her for 30 years' 
Frâncu $(1969$, p. 305) concludes that the form $o$ originates in $a u$, and the written forms $o$ - $u$ and $o o$ represent the initial stage of the assimilation of $a$ from au, favoured by the presence of a rounded vowel. Another argument for this conclusion comes the fact that, in the old language, $o$ only occurs in the areas where au is exclusively used for singular and plural and that in the present-day language au is attested only in the areas where $o$ is also used.

3.2. Gheție (1975, p. 171) shows that in Moldavia the new form $o$ emerges soon after 1600 (4). In Transylvania, $o$ is attested at the beginning of the $17^{\text {th }}$ century and frequently shows up in original documents after 1700. In Banat, an area for which the first preserved original documents are from the $18^{\text {th }}$ century, $o$ is attested only once (5).
(4) a. o crescut
O grow.PPLE
b. $o$ dat
O give.PPLE
c. $s-o \quad p u s$
CL.REFL $=\mathrm{O}$ put.PPLE
d. $o$ ţinut
O keep.PPLE
(1615)
(5) o cumpărat-o
O buy.PPLE $=$ CL.ACC.F.3SG
'he bought it'

3.3. Zamfir (2007, p. 111) suggests the same timing: $o$ is an innovation of the $17^{\text {th }}$ century, which was not attested in the previous century. Working on a larger corpus, especially on more recently edited original documents, Zamfir (2007, p. 112) reaches more nuanced results than her predecessors: in old Romanian, $o$ had an inverse distribution when compared to that of the present-day language: in the first period of old Romanian, she identifies 12 occurrences in original documents from Wallachia (not taken into account by Frâncu) and two occurrences in Moldavia.

Zamfir (2007, p. 111) shows that the initial stage identified by Frâncu (1969), illustrated with examples from the inscriptions from Maramureș, is also attested quite frequently in Southern original documents. The author quotes examples in which the auxiliary au preceded by the clitic $o$ is elided, the result being the semivowel $u$ :

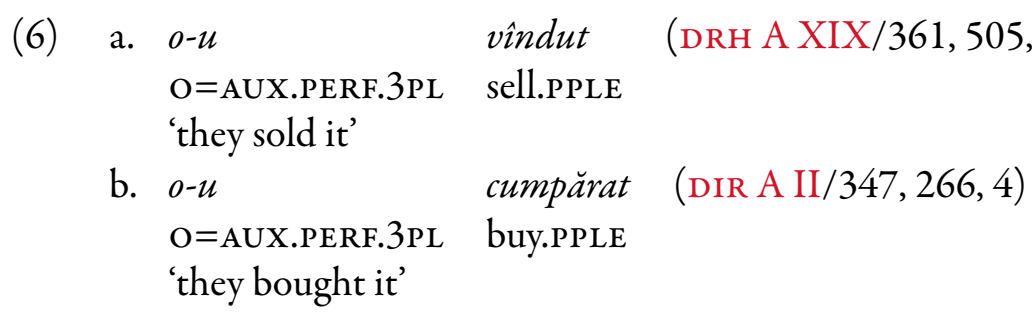

Significantly, of the 15 occurrences of the auxiliary $o$ identified by Zamfir (2007), in 12 this element occurs in contexts in which the presence of the clitic $o$ is syntactically required-that is, with transitive verbs (7) - but in which, in contrast to (6), there are no relics of the original form of the auxiliary.

$$
\begin{array}{ll}
\text { (7) } o[<o o] & \text { datu } \\
\mathrm{O} & \text { give.PPLE } \\
o[<o o] & \text { vindut } \\
\mathrm{O} & \text { sell.PPLE }
\end{array}
$$




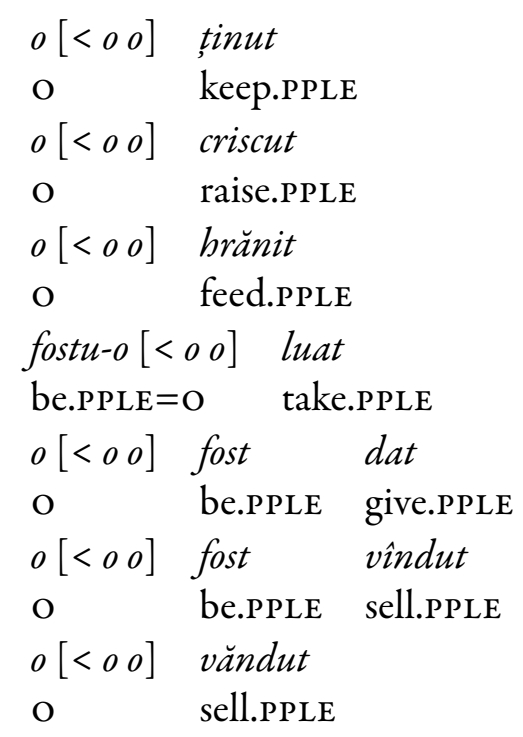

Therefore, the form $o$ in contexts such as $o$ a $u$ CL.ACC.F.3SG=AUX.PERF.3SG $\equiv$ PL represents a step forward in comparison with the elided forms (Zamfir, 2007, p. 113). Moreover, elision also affects other forms of the auxiliary (8), therefore there is no necessary link between elision and the emergence of a systematic variant $o$ for the $3^{\text {rd }}$ person perfective auxiliary.
(8) o-mu
vîndutu
CL.ACC.F.3SG $=$ AUX.PERF.1SG $\equiv P L \quad$ sell.PPLE

The author concludes that $o$ attested in the Wallachian original documents is a pseudo-auxiliary which incorporates two elements: the pronominal clitic $o$ and the $3^{\text {rd }}$ person form of the perfective auxiliary.

Zamfir (2007, p. 113) also has an important contribution for the dating and localization of the plural form $\operatorname{or}(u)$ characterizing today the area of Banat, which she attests for the first time in an original document from Wallachia (9); she nevertheless suggests that the copyist was from Banat.
(9) oru fäcut (DRH B XXIII/436, 636, 8, 1632)
AUX.PERF.3PL do.PPLE 'they did'

Finally, another relevant observation is that the phonetic structure of the perfective auxiliary in old Romanian, for all the persons, is, in many cases, altered because the auxiliary often clusters together with other monosyllabic forms, especially with pronominal clitics. Therefore, the phonetic shape of the auxiliary is prone to a strong "vulnerability" (Zamfir, 2007, p. 114).

3.4. An investigation of the $19^{\text {th }}$ century (Dragomirescu, 2012, p. 204) shows that in this period $o$ did not belong to the standard language either. Until 1880, in Moldavia, the form au is almost general but certain grammars also mention the forms $a$ and $o$. Although the grammars do not recommend this form, $o$ is (rarely) used by Moldavian writers:
a. $s-o$
fudulit,
CL.REFL $=$ AUX.PERF.3SG $\equiv \mathrm{PL}$ show.off.PPLE
te-o
apucat
CL.ACC.2SG $=$ AUX.PERF.3SG $\equiv$ PL catch.PPLE
(Alecsandri)
'he/they showed off', 'he caught you'
b. s-o-ntîlnit
(Conachi)
CL.REFL $=A U X . P E R F .3 S G \equiv P L=$ meet.PPLE
'they met' 
3.5. Therefore, there is agreement in the literature on the fact that the perfective auxiliary $o$ emerged at the beginning of the $17^{\text {th }}$ century. The diachronic data suggest that there is no direct relation between the future auxiliary and the perfective forms $o$ and or. Another common point seems to be the relation between the auxiliary $o$ and the pronominal clitic $o$ (possibly, other pronominal clitics too).

As far as the origin of this innovation is concerned, the information differs: Frâncu (1969) identifies the form $o$ only in Moldavian original documents and the hybrid forms (such as $o o$ or $o=$ auxiliary + clitic) in inscriptions from Maramures,, whereas Zamfir (2007) discovers not only the form $o$ (auxiliary or clitic + auxiliary), but also hybrid forms $(o-u)$ especially in Wallachia. For the purpose of this analysis, we will endorse the hypothesis that $o$ emerged from au by assimilation, under the right phonetic conditions: the vowel /a/, whose features are [central, open, non-rounded], is partially assimilated by the vowel $/ \mathrm{u} /$, characterized by the features [back, close, rounded], the result being the vowel/o/, which is [back, openmid, rounded], therefore preserving all the features of $/ \mathrm{u} /$, except for the aperture, which changes under the influence of the open vowel /a/.

We should also keep in mind the idea that, in the old language, the perfective auxiliary was phonetically very vulnerable in the regional varieties.

In the next section we will analyse the distribution of the auxiliary $o$ in the Moldavian variety, first of all in linguistic atlases and then in texts; we will try decide whether there are restrictions related to the syntactic class of the lexical verb (whether the auxiliary $o$ is preferred with transitive verbs, in which the pronominal clitic $o$ can also occur) and to the presence of other clitic elements.

\section{The auxiliary $o$ in the Moldavian variety. The relation with cliticization}

In contrast to other Northern varieties, in Moldavia, the auxiliary $o$ is used both for the singular and for the plural; a special form for the plural, such as or in other areas, is not attested in this variety.

\subsection{The data in the linguistic atlases}

In this section, we analyse certain maps from ALR s.n. V and VI and from ALR I, which contain compound perfect forms for the $3^{\text {rd }}$ person singular, co-occurring with pronominal clitics, in order to see which forms are preferred in Moldavia.

(i) On map 1625, (Calul) mi l-a dat tata horse.DEF CL.DAT.1SG=AUX.PERF.3sG give.PPLE father.DEF 'Father gave me the horse' (ALR s.n. VI), the form $o$ occurs 11 times, whereas the form $a$ only twice.

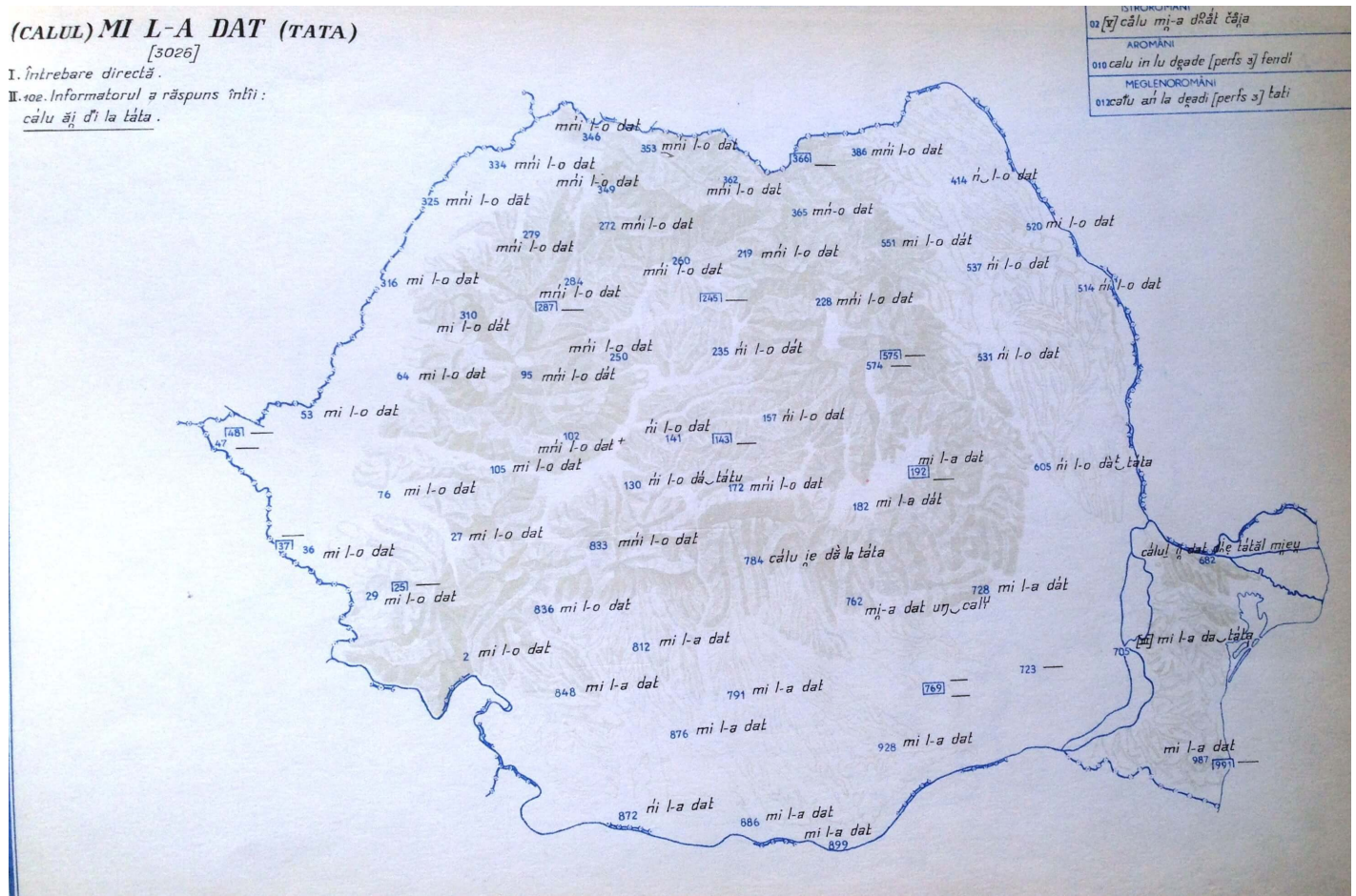


(ii) On map 1630, Cine ți-a dat plăcintă who CL.DAT.2sG=AUX.PERF.3SG give.PPLE pie 'Who gave you pie?' (ALR s.n. VI), $o$ is used 9 times and $a$ twice:

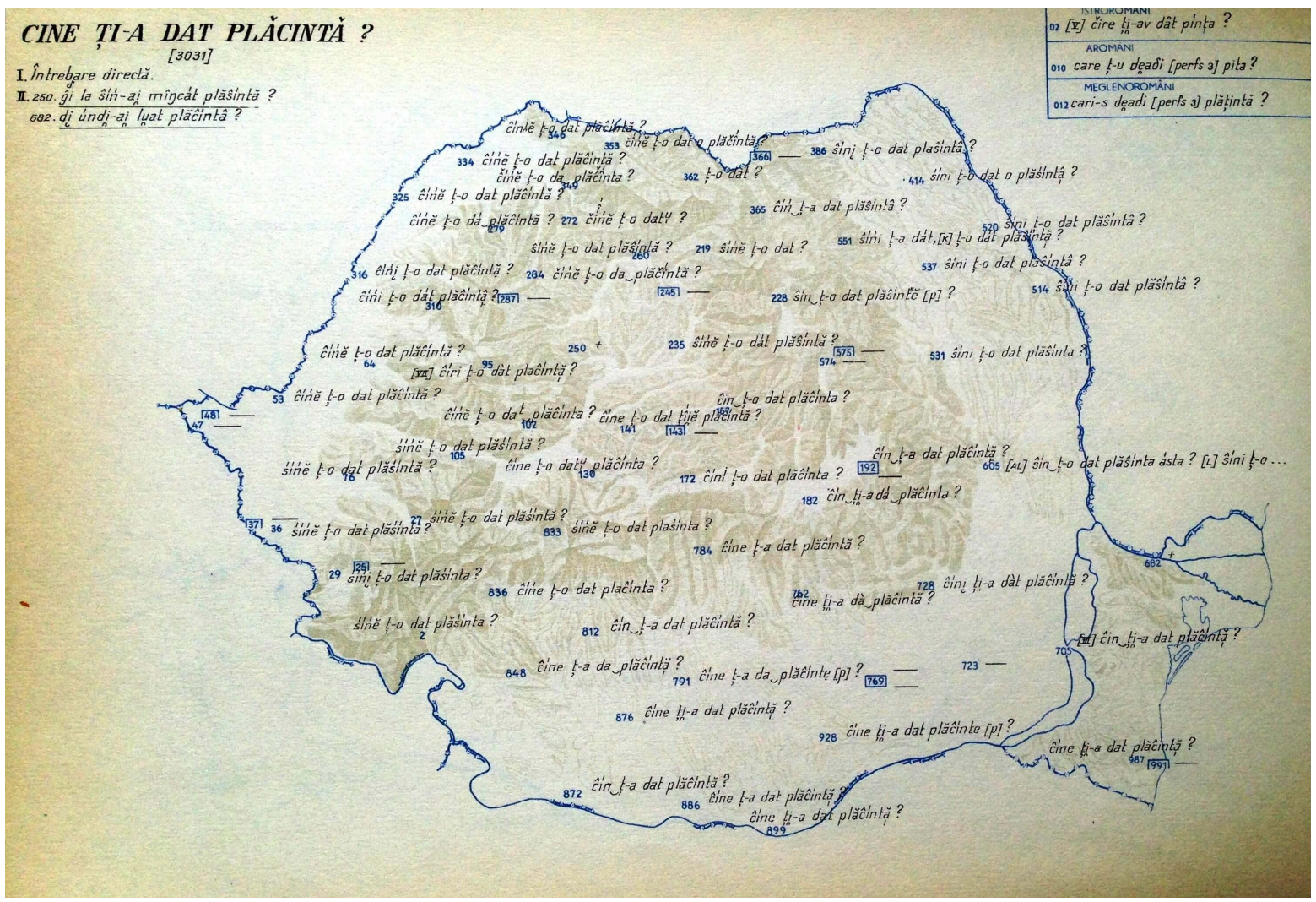

(iii) On map 1642, Penoi ne-a văzut tata DOM us CL.ACC.1 PL=AUX.PERF.3sG see.PPLE father.DEF 'Father saw us' (ALR s.n. VI), $o$ shows up 8 times and $a$ twice:

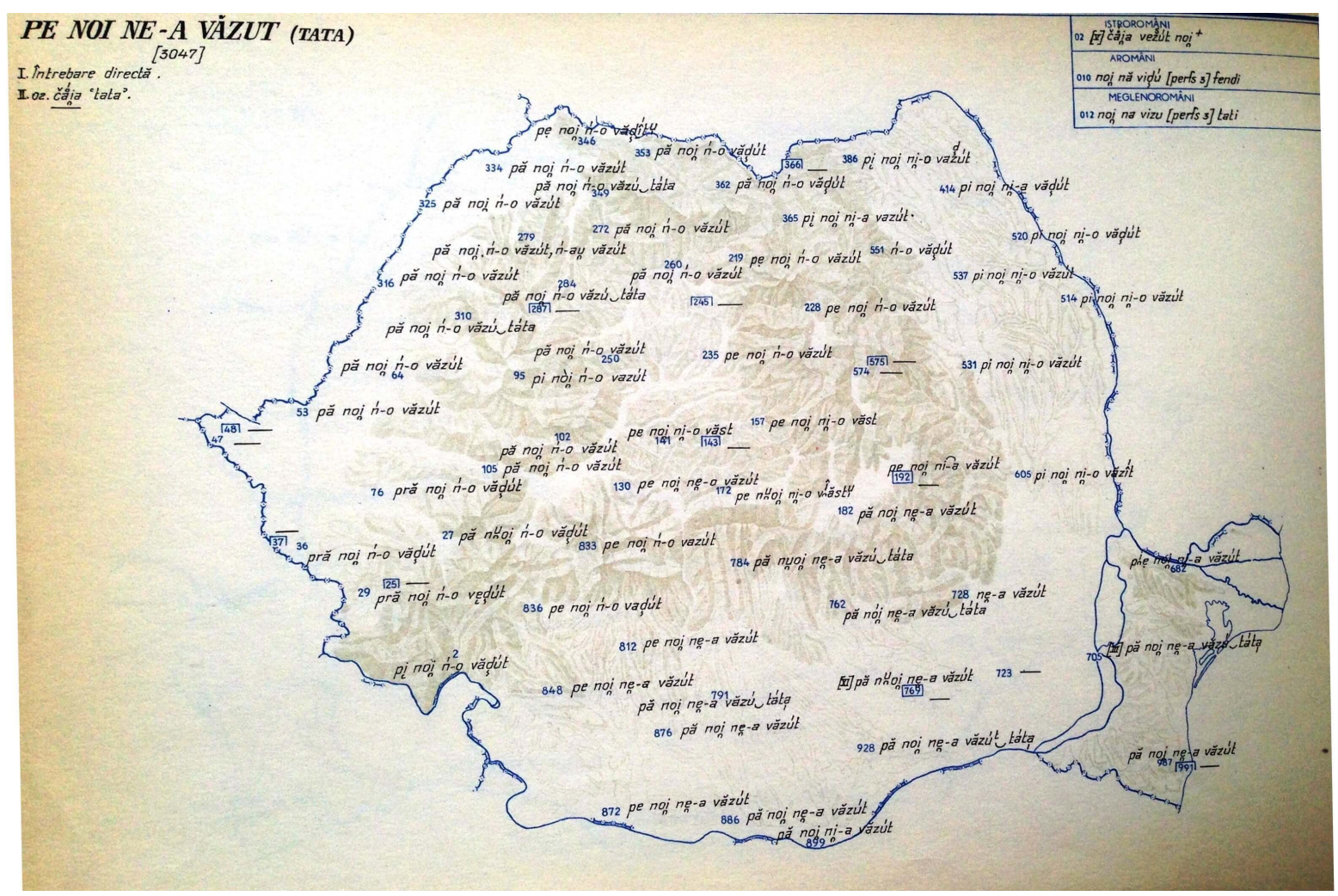


(iv) On map 1455, S-a minjit (cu funingine pe față) CL.REFL=AUX.PERF.3sG soil.PPLE with soot on face 'He soiled his face with soot' (ALR s.n. V), $o$ is used nine times, while $a$ is used twice:

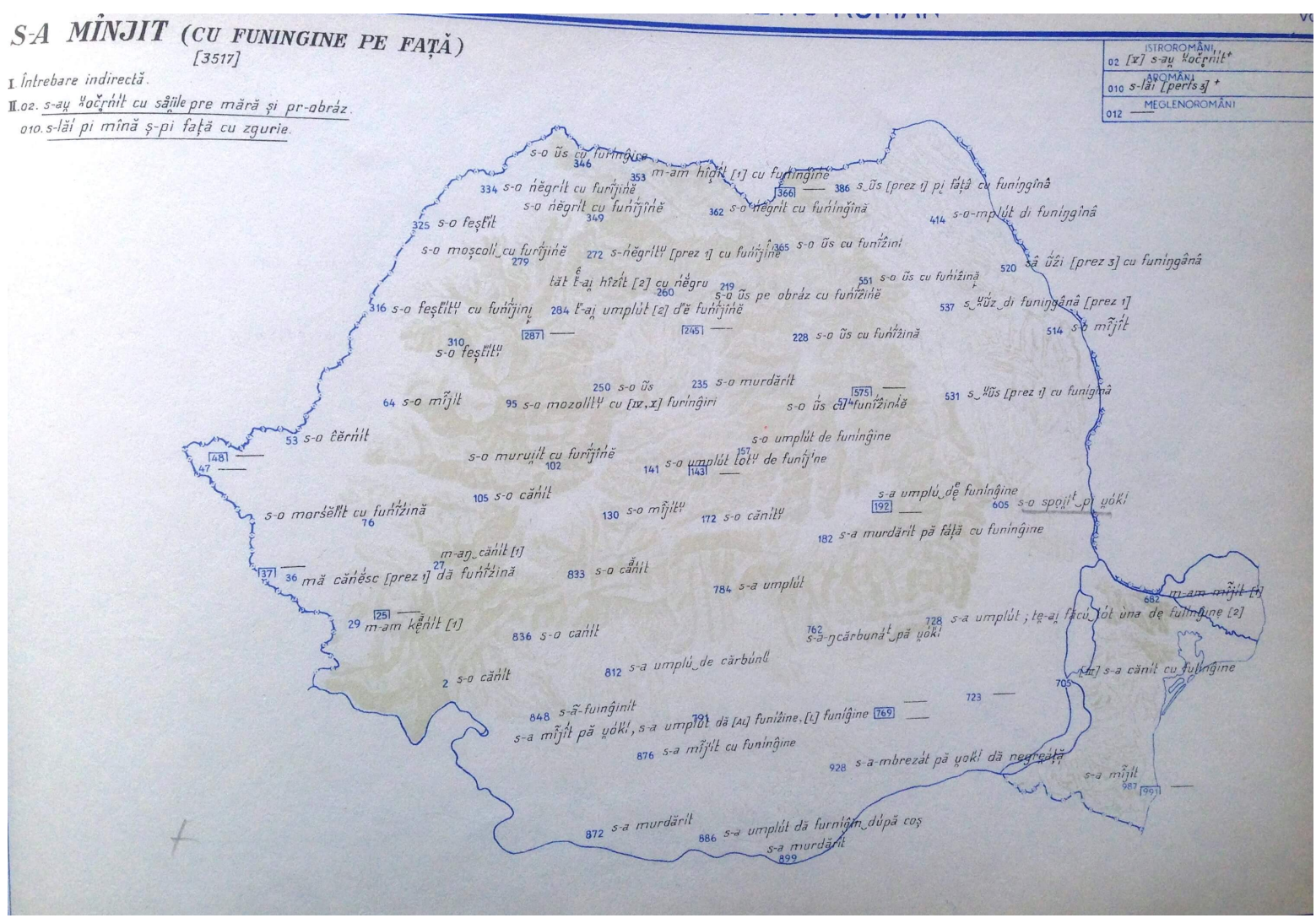

(v) On map 1706, ... I-a murit bărbatul CL.DAT.3sG=AUX.PERF.3sg die.PPLE husband.DEF 'Her husband died' (ALR s.n. VI), there are eight occurences of the form $o$ and two of the form $a$ :

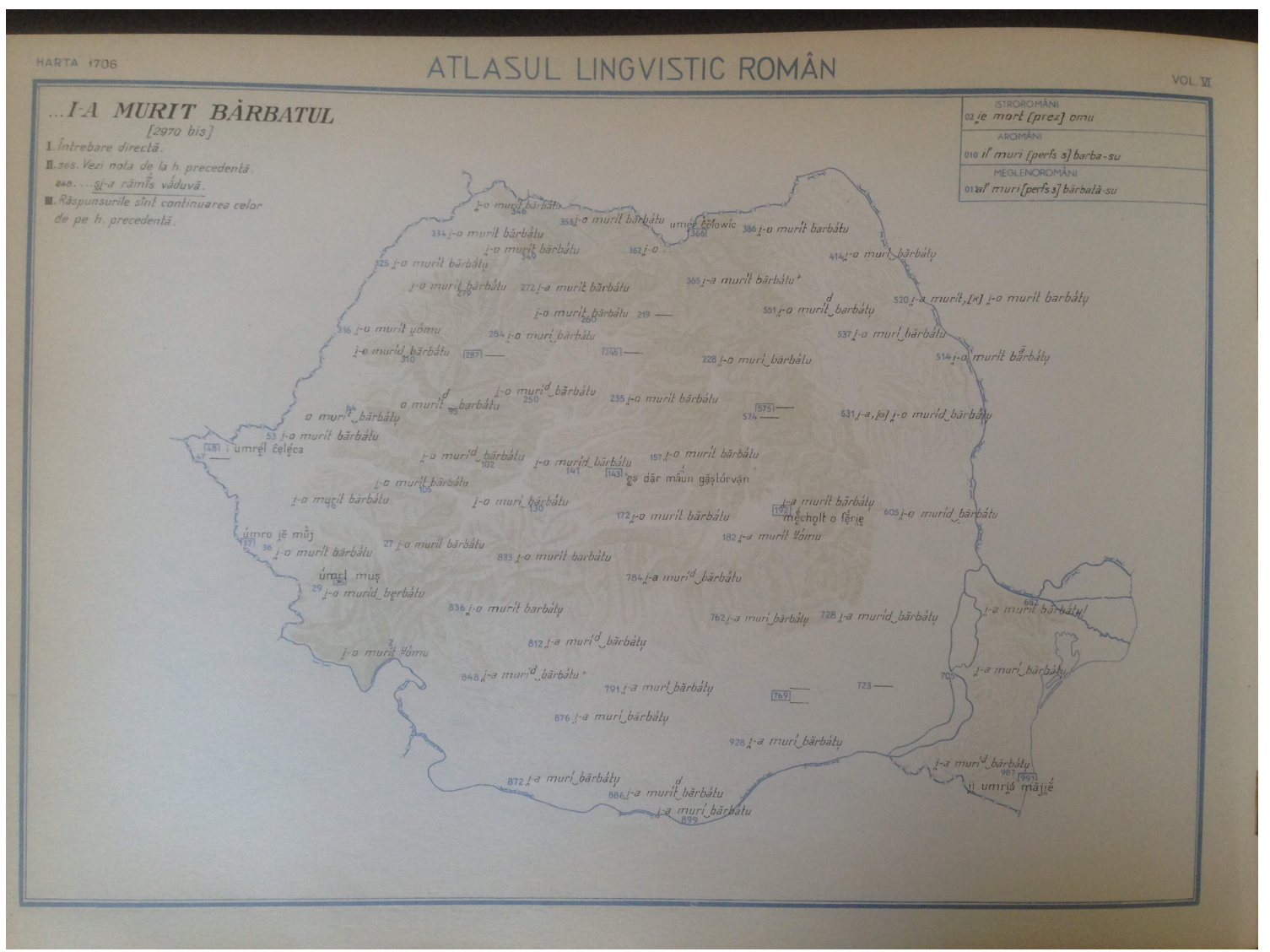


(vi) On map 302, Aşa mi-a fost soarta like.this CL.DAT.1sG=AUX.PERF.3sg be.PPLE fate.DEF 'This has been my fate' (ALR I, vol. II, part II) $o$ is used in 49 points, while $a$ is preferred in 12 points:

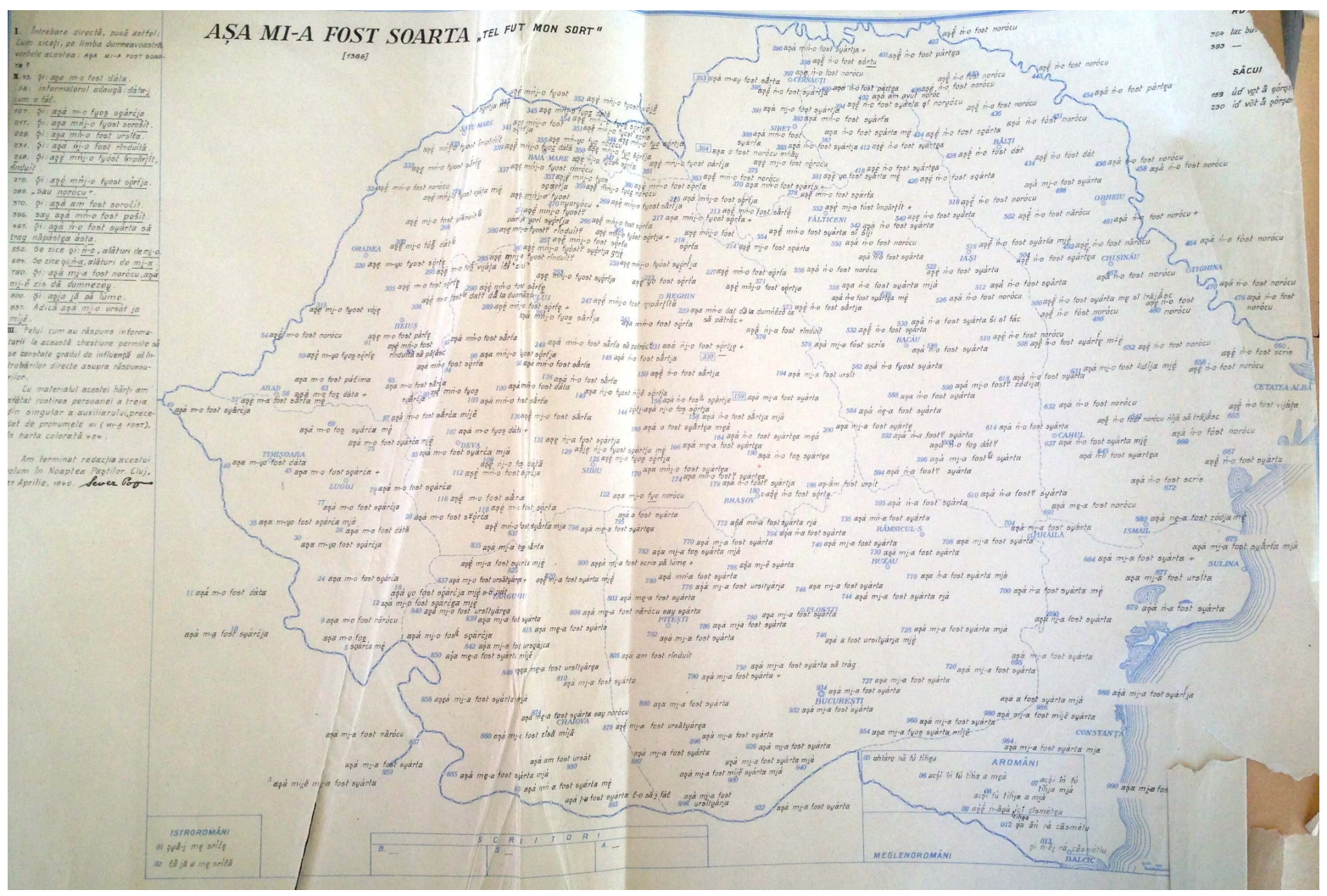

The analysis of these maps shows that $o$ is preferred in the entire area of Moldavia, except for certain villages in the South, where $a$ is employed. From these maps, it is apparent that $o$ is compatible not only with transitive verbs [(i)-(iv)], but also with intransitives [(v)-(vi)]; the data in the maps are not relevant for the relation with cliticization, because the same situation is encountered as well when the auxiliary is not accompanied by pronominal clitics (for example, on the maps Atîția au venit 'So many came', A făcut ce-a facut 'He did what he did', and $A u$ ars 'They burned' from ALR s.n.). Thus, according to the atlases, the form $o$ is general in Moldavia (except the few Southern points), irrespective of the presence of pronominal clitics. Roughly speaking, the atlases confirm the description in the dialectological handbooks.

\subsection{The data from texts}

The texts analysed in this research belong to three categories (see also Botez, 2016), which illustrate different moments (from the $20^{\text {th }}$ and the $21^{\text {st }}$ centuries) and have a different geographical distribution (in Moldavia):

(i) older texts (from 1930-1960), collected from the entire territory where the Moldavian variety is spoken, included in the volume published by Emil Petrovici as a supplement to ALR II (referred to as TD below) and in Caragiu Marioțeanu et al. (1977) (referred to as DR below);

(ii) dialectal texts (from 1968-1972) included in the supplement to NALR, volume I, part II (the counties Vrancea, Galați and Bacău), published by Stelian Dumistrăcel in 1995;

(iii) new texts by Mădălina Botez, made in 2016 in two villages from the county of Neamț (Grințieșu Mare and Poiana, form the Grințieș commune) and in Tîrgu Neamţ.

With respect to the relation between the auxiliary $o$ and the transitivity of the lexical verb (see the discussion from Zamfir, 2007 above), it is worth mentioning that in the texts under analysis the auxiliary $o$ equally combines with transitive (11) and intransitive (12) verbs. 
$(11)$
a. $o$ dat $(\mathrm{TD}, 166)$
O give.PPLE
b. o văzutî (TD, 197)
O see.PPLE
c. $\quad$ facut (TD, 202)
o do.PPLE
(12) a. o vinit (TD, 166, 180,201, 208)
O come.PPLE
b. $\quad$ stat (DR, 236)
O sit.PPLE
c. $O$ plecat (DR, 236)
o leave.PPLE

In the dialectal texts from (i), we have identified 31 structures with $o$ without other clitics, 23 for the singular (13a) and 8 for the plural (13b). In 60 contexts, $o$ is accompanied by pronominal clitics, by coordinating and subordinating conjunctions, 52 forms being used for the singular $(14 \mathrm{a}-\mathrm{c})$ and 8 for the plural (14d). The standard form $a$ does not occur in these texts, whereas au occurs only once as a singular (15a) and once with a plural value (15b).

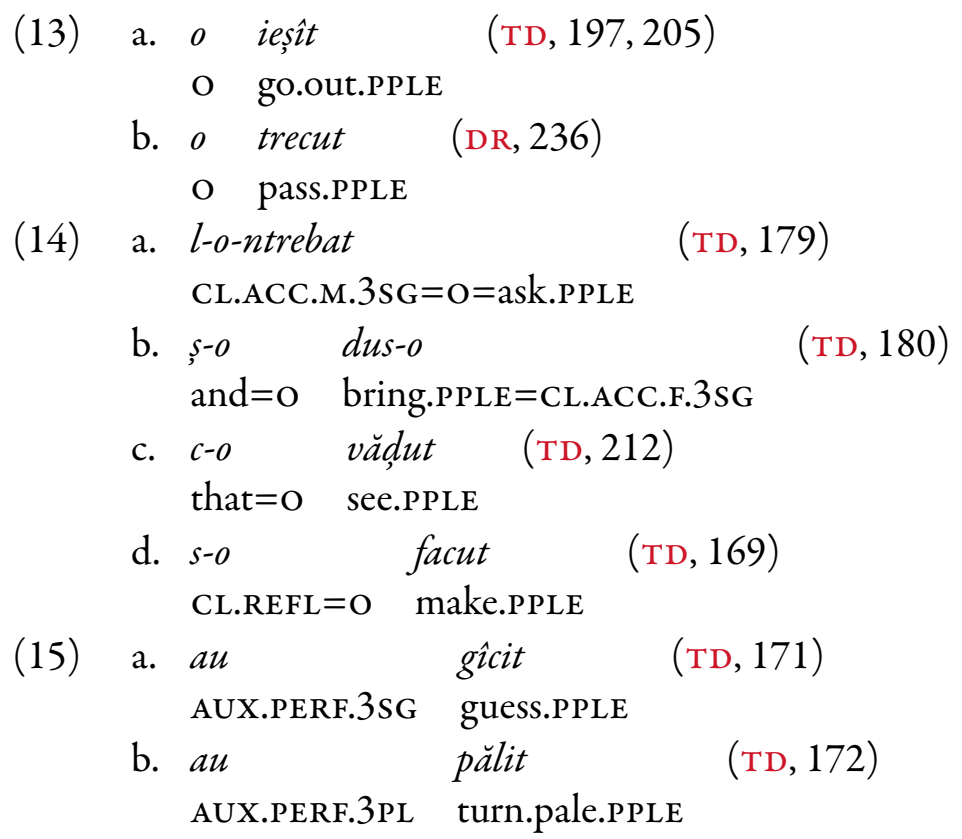

In the texts under (ii), we have identified 19 contexts with $o$ unaccompanied by pronominal clitics (16) and 71 contexts with $o$ co-occurring with pronominal clitics and coordinating and subordinating conjunctions (17). The standard forms $a$ (for singular and plural) and $a u$ (for plural) occur without other clitic elements in 135 context (18) and with other clitics in 196 contexts (19).
a. o intrat (NALR, 15)
O enter.PPLE
b. $o$ vinit (NALR, 15)
O come.PPLE
a. $m-o$
lovit
un mînz (NALR, 15)
CL.ACC.1SG $=\mathrm{O}$ kick.PPLE a colt 'a colt kicked me' 
b. c-o fost (NALR, 21) that $=\mathrm{O}$ be.PPLE
a. a
sărit
cu toțî
(NALR, 23)
AUX.PERF.3PL jumP.PPLE with all

'They all jumped'

b. a

$$
\text { liegat vaca (NALR, 12) }
$$

AUX.PERF.3SG tie.PPLE cOW.DEF

'he tied up the cow'

(19)
a. $m-a$
trimes părințî
(NALR, 238)
CL.ACC.1SG=AUX.PERF.3SG send.PPLE at parents 'he sent me to my parents'
b. s-au dus (NALR, 12)
CL.REFL $=A U X . P E R F .3 P L \quad$ gO.PPLE
'they left'

In the texts under (iii), we have identified 25 constructions with $o$ unaccompanied by other clitics, 22 for the singular (20a) and 3 for the plural (20b) and 31 constructions with $o$ co-occurring with pronominal clitics, coordinating and subordinating conjunctions, and relative pronouns, 24 for the singular $(21 \mathrm{a}-\mathrm{c})$ and 7 for the plural $(21 \mathrm{~d}-\mathrm{e})$. We have also identified 5 standard forms, all for the plural, among which 4 occur without other clitics (22) and one in which au attaches to the $w$-element $c e$ ' what' (in the Moldavian pronunciation $\left.\left[\int \mathrm{e}\right]\right)(23)$.

$(20)$
a. $o$ fost
o be.PPLE
b. $o$ vint
O come.PPLE

(21)
a. $m-0$
ajutat
CL.ACC.1sG $=\mathrm{O}$ help.PPLE
'he helped me'
b. $s-o \quad z \hat{\imath} s$
and $=O \quad$ say.PPLE
'and he said'
c. $c-0$ fost
that $=\mathrm{O}$ be.PPLE
'that he was'
d. nu prea s-o dus
not really CL.REFL $=O$ go.PPLE
'they did not really go'
e. cari-o fost
which.PL $=\mathrm{O}$ be.PPLE
'which was'

(22)

a. au

facut

AUX.PERF.3PL do.PPLE

b. au

fost

AUX.PERF.3PL be.PPLE

c. au

vrut

AUX.PERF.3PL want.PPLE

(23) ss-au facut

what $=$ AUX.PERF.3PL do.PPLE

'What did they do?' 
In Table 2, we synthesize the results of the corpus study; the factors relevant for our research purposes have been boldfaced.

\begin{tabular}{lccccc} 
Source & $\begin{array}{c}\boldsymbol{o} \text { [+ clitics, } \\
\text { conjunctions] }\end{array}$ & $\begin{array}{c}\boldsymbol{o} \text { [- clitics, } \\
\text { conjunctions] }\end{array}$ & $\begin{array}{c}\boldsymbol{a} \text {, au [+ clitics, } \\
\text { conjunctions] }\end{array}$ & $\begin{array}{c}\boldsymbol{a}, \boldsymbol{a u} \text { [- clitics, } \\
\text { conjunctions] }\end{array}$ & Total \\
\hline DR, TD & $\mathbf{6 0}$ & 31 & & 2 & 93 \\
$(1930-1960)$ & $(\mathbf{6 4 , 5 2 \% )}$ & $(33,33 \%)$ & - & $(2,15 \%)$ & $(100 \%)$ \\
\hline NALR (total) & 71 & 19 & 196 & 135 & 421 \\
$(1968-1972)$ & $(16,86 \%)$ & $(4,51 \%)$ & $(46,56 \%)$ & $(32,07 \%)$ & $(100 \%)$ \\
\cline { 2 - 6 } & 33 & 8 & 126 & 75 & 242 \\
a. Vrancea & $(13,63 \%)$ & $(3,30 \%)$ & $(52,07 \%)$ & $(31 \%)$ & $(100 \%)$ \\
\cline { 2 - 6 } & $\mathbf{1 7}$ & 3 & 11 & 4 & 35 \\
b. Galați & $(\mathbf{4 8 , 5 8 \% )}$ & $(8,57 \%)$ & $(31,42 \%)$ & $(11,43 \%)$ & $(100 \%)$ \\
\cline { 2 - 6 } & 21 & 8 & 59 & 56 & 144 \\
c. Bacău & $(\mathbf{1 4 , 5 8 \% )}$ & $(5,56 \%)$ & $(40,97 \%)$ & $(38,89 \%)$ & $(100 \%)$ \\
\hline Recordings & $\mathbf{3 1}$ & 25 & 1 & 4 & 61 \\
(Neamț, 2016) & $(\mathbf{5 0 , 8 2 \% )}$ & $(40,98 \%)$ & $(1,64 \%)$ & $(6,56 \%)$ & $(100 \%)$
\end{tabular}

Table 2: The distribution of the forms $o$ vs $a$, au in texts from Moldavia

The statistical data in the table, although not unitary, suggest that: (i) the texts from the first category, recorded in the first half of the $20^{\text {th }}$ century, roughly confirm the information from the dialectological treatises and from the linguistic atlases, according to which the form $o$ is general in Moldavia; (ii) in the texts from the second category, recorded in the second half of the $20^{\text {th }}$ century in the Southern region of Moldavia, the percentages are unequal: the standard forms are preferred in Vrancea and Bacău, whereas the texts from Galați show a preference for the form $o$, especially when it co-occurs with other clitics; (iii) the texts from the last category, from the North, show a clear preference for the form $o$, independently of the existence of other clitic elements.

\section{Conclusions}

Our synchronic and diachronic analysis of the perfective auxiliary $o$ in the Moldavian variety points to the following conclusions:

(i) the auxiliary $o$ developed from $a u$ by assimilation, and the context which favoured this change involves the existence of other clitics, especially the pronominal clitic $o$-see examples (1)-(3), (4c-d), (5)-(7);

(ii) the auxiliary $o$ is first attested at the beginning of the $17^{\text {th }}$ century; similarly to the present-day situation, it has always been a non-standard form ${ }^{1}$, belonging to the spoken language;

(iii) the data from the dialectological treatises and from the linguistic atlases, as well as the texts from DR and TD, suggest that the form $o$ is (quasi)general in Moldavia;

(iv) the data from other texts, more recently collected, suggest, on the one hand, that the form $o$ is used alongside the standard forms $a$ and $a u$ (probably under the pressure of the standard language, especially in the Southern part of Moldavia) in similar contexts, and, on the other hand, that there is an incipient tendency towards the specialization of the form $o$ for contexts with multiple phonological cliticization.

Besides the descriptive conclusions, we can also put forth the hypothesis that the current situation of the Moldavian variety is determined by the contact with the standard language, a special type of linguistic

\footnotetext{
${ }^{1}$ In order to verify once more the usage of the auxiliary $o$ in literary texts, we have surveyed two old texts published in Moldavia, Prav.1581 and șT.1644. The form $o$ is not attested in these texts.
} 
contact, which implies competition (in this case, between the form $o$ and the forms a/au) and change (Van Coetsem, 1992, p. 27). The transfer from the source-variety (the standard language) and the target-variety (the Moldavian one) involves a process of over-differentiation, opposed to the under-differentiation Weinreich, 1953, p. 18), in which, due to reasons still hard to understand ${ }^{2}$, the form $o$ manifests the tendency towards the specialization for contexts in which other clitics are present, whereas the standard variants $(a, a u)$ are preferred in the absence of other clitics.

\section{Bibliography}

\section{A. Corpus}

A.1620 = Alexandria, in Zgraon, Fl. (ed.), Cele mai vechi cărți populare în literatura română, vol. 11, Fundația Națională pentru Ştiință și Artă, București, 2006.

ALR I = S. Pop, Atlasul lingvistic român, vol. I, coord. S. Pușcariu, partea a II-a, Otto Harrassowitz, Sibiu/Leipzig, 1942.

ALR s.n. V = Atlasul lingvistic român, serie nouă, vol. V, Editura Academiei, București, 1966.

ALR s.n. VI = Atlasul lingvistic român, serie nouă, vol. VI, Editura Academiei, București, 1969.

$\mathrm{DB}=$ Bianu, I. (1907). Documente româneşti, București.

DIR A II = Documente privind istoria României. Veacul XVII. A. Moldova, vol. II (1606-1610), Editura Academiei, București, 1953.

DR = Caragiu Marioțeanu, M., Giosu, Ș., Ionescu-Ruxăndoiu, L. \& Todoran, R. (1977). Dialectologie română, Editura Didactică și Pedagogică, București.

DRH A XIX = Documenta Romania Historica. A. Moldova, vol. XIX (1626-1628), Editura Academiei, București, 1969.

DRH A XXI = Documenta Romania Historica. A. Moldova, vol. XXI (1632-1633), Editura Academiei, București, 1971.

DRH B XXIII = Documenta Romania Historica. B. Țara Românească, vol. XXIII (1630-1632), Editura Academiei, București, 1969.

IM = Bîrlea, I. (1909). Însemnări din bisericile Maramureșului, București.

NALR = Duminstrăcel, S. (1995). Noul atlas lingvistic român pe regiuni. Moldova și Bucovina, I, Partea a 2-a, Editura Academiei

Române, Iași.

po.1582 = Pamfil, V. (ed.) (1968). Palia de la Orăștie, Editura Academiei, București.

Prav.1581 = Rizescu, I. (ed.) (1971). Pravila ritorului Lucaci, Editura Academiei, București, p. 161-183.

ș. 1644 = Mazilu, I. (ed.) (2012). SSeapte taine a besearecii, Iași, 1644, Editura Universității „Alexandru Ioan Cuza”, Iași, p. 173259.

TD = Petrovici, E. (1943). Texte dialectale. Suplement la Atlasul lingvistic român II, Muzeul Limbii Române/Otto Harrassowitz, Sibiu/Leipzig.

\section{B. References}

Botez, M. (2016). O analiză morfologică a auxiliarelor de perfect compus şi de viitor in graiul din Moldova, communication at BEST Letters Colloquia, $3^{\text {rd }}$ edition, București, 28-29 octombrie.

Caragiu Marioțeanu, M., Giosu, Șt., Ionescu-Ruxăndoiu, L. \& Todoran, R. (1977). Dialectologie română, Editura Didactică și Pedagogică, București.

Coteanu, I. (1961). Elemente de dialectologie a limbii române, Editura Științifică, București.

Dragomirescu, A. (2012). Verbul [secolul al XIX-lea], in Chivu, Gh., Pană Dindelegan, G., Dragomirescu, A., Nedelcu, I. \& Nicula, I. (eds) Studii de istorie a limbii române. Morfosintaxa românei literare in secolele al XIX-lea - al XX-lea, Editura Academiei Române, București, 2012 (revised edition, 2015), p. 185-222.

Frâncu, C. (1969). Formele de persoana a III-a ale auxiliarului de la perfectul compus. Privire istorică, in "Studii și cercetări lingvistice", vol. XX, nr. 3, p. 299-318.

Gheție, I. (1975). Baza dialectală a românei literare, Editura Academiei, București.

Ledgeway, A. (2017). Parallels in Clausal and Nominal Structures: Romanian Clitic Placement, în Dragomirescu, A., Nicolae, A., Nicula Paraschiv, I. \& Pană Dindelegan, G. (eds), Romance Syntax. Comparative and Diachronic Perspectives, Cambridge Scholars Publishing, Newcastle (sub tipar).

$\mathrm{TDR}=$ Tratat de dialectologie românească, Editura Scrisul Românesc, Craiova, 1984.

Van Coetsem, F. (1992). The Interaction between Dialect and Standard Language, and the Question of Language Internationalization, in Van Leuvensteijn, J. \& Berns, J. (eds), Dialect and Standard Language. Dialekt und Standardsprache in the English, Dutch, German, and Norwegian Language Areas, Royal Netherlands Academy of Arts and Sciences, Amsterdam/Oxford/New York/Tokyo, p. 15-70, [online].

\footnotetext{
${ }^{2}$ We could not identify a precise phonetic context which favours the usage of the form $o$. For similar conclusions related
} to the position of the pronominal clitic $o$, see Ledgeway (2017). 
Weinreich, U. (1953). Languages in Contact. Findings and Problems, Mouton, The Hague, Crossref.

Zamfir, D.-M. (2007). Morfologia verbului în dacoromâna veche (secolele al XVI-lea - al XVII-lea), vol. II, Editura Academiei Române, București. 